\title{
血液透析患者における貧血改善後のリコンビナント・ ヒト・エリスロポエチンの維持投与の検討
}

\author{
中塚喜義日野雅之三木隆己西沢良記 \\ 甶 畑 勉* 井上隆* 森井浩世 \\ 大阪市立大学第 2 内科 蒼龍会井上病院 ${ }^{*}$ \\ (平成 1 年 6 月 22 日受付，同年 8 月 7 日受理)
}

key words：腎性貧血, 血液透析, rEPO, ヘマトクリット, 維持投与

〈要旨〉

著明な貧血を呈する慢性腎不全血液透析患者にリコンビナント・ヒト・EPO (rEPO) を投与し，賓血改善後至適へ マトクリット $(\mathrm{Ht})$ 值を維持するのに有効な投与方法を検討した. 初期投与法は 34 例全例 3,000 IU 週 3 回で行い, $\mathrm{Ht}$ 值が $27 \%$ に達した時点より維持投与に移行した. 維持投与としては予め無作為に A, B に分け, Ht 值を 27 ～33\% に維持するように, 3,000 U で週投与回数を減少あるいは増加する（A群), または週 3 回投与で 1 回投与量を減量 あるいは増量する (B 群) することとした。

この結果, 初期投与ではrEPO 投与 1 週後より有意の $(p<0.001) \mathrm{Ht}$ 值の上昇を認め, $3 \sim 12$ 週間で Ht $27 \%$ に達 し維持投与に移行した.

維持投与後 A, B ともに目標 $\mathrm{Ht}$ 值 27〜33\%内に良好にコントロールされた. 維持投与の評価では群間で有意差を 認めず, A, B 群間の週当りの総投与量が異なる点を考慮する必要があるが, A群で Ht 值の目標維持レベルを外れる 症例が多く $\mathrm{Ht}$ 維持のばらつきが大きい傾向にあった。これらのことより，維持投与方法としては投与間隔を拡げる (A.群) よりも，1 回投与量を減ずる（B群）の方が Ht 值を一定レベルに維持するのに有効であると考えられた.

血液透析毎に週 3 回投与は血中エリスロポエチンレベルをある有效濃度に保ち, 標的細胞である後期赤芽球前駆細 胞および关れ以前の赤芽球系幹細胞の分化誘導の持続に重要であることも示唆された.

副作用は 4 例 $(11.8 \%)$ において認められ，いずれも血圧上昇, 頭痛であったが投与を継続することが可能であっ た.

Maintenance administration of recombinant human erythropoietin in hemodialysis patients after the improvement of renal anemia

Kiyoshi Nakatsuka, M. D., Masayuki Hino, M. D., Takami Miki, M. D., Yoshiki Nishizawa, M. D., Tsutomu Tabata, M. D.*, Takashi Inoue, M. D.*, Hirotoshi Morii, M. D.

Second Department of Internal Medicine, Osaka City University Medical School ; Inoue Hospital*

Recombinant human erythropoietin (rEPO) was administered to chronic hemodialysis patients with severe anemia in doses of 3,000 IU three times a week as an initial treatment. Then maintenance treatments which increased/decreased the frequency or amount of doses were evaluated. Thirty-four patients were randomily divided into Groups A and B. To maintain the hematocrit $(\mathrm{Ht})$ in the range of 27 to $33 \%$, either the frequency of dosing (Group A) or the dosage (Group B) was adjusted, depending on the $\mathrm{Ht}$ value. A significant increase in $\mathrm{Ht}$ ( $\mathrm{p}<0.001$ ) was observed after one week, after which, all patients reached $\mathrm{Ht}$ values of over $27 \%$ from 3 to 12 weeks.

When shifting to maintenance treatment, $\mathrm{Ht}$ values were well controlled within the objective range, 27 to $33 \%$, in both groups. There was no statistically significant difference between the two groups according to analysis of

中塚 喜義 大阪市立大学第 2 内科

于 545 大阪市阿倍野区旭町 1-5-7 (06-645-2111) variance. However, the $\mathrm{Ht}$ values of Group A tended to deviate more from the objective range than those of 
Group B. Despite a lower total weekly dosage at a constant frequency, the dose adjustment method (Group B) was more effective in maintaining $\mathrm{Ht}$ in the range of $30 \pm 3 \%$, than constant dosing at variable frequencies (Group $\mathrm{A}$ ).

It is suggested that maintaining an effective concentration of serum erythropoietin by three-times-a-week administration of rEPO at hemodialysis is important to maintain the differentiation and induction of erythroid progenitor and precursor cell.

Adverse affects, including increased blood pressure and headache, appeared in four patients $(11.8 \%)$, but rEPO treatment could be continued.

\section{緒言}

慢性腎不全患者，特に維持透析に至った患者に必発す る貧血（腎性貧血）はその体力とくに持久力の低下をも たらし社会復帰を妨げる重要な要因となっている1).

腎性貧血と一括される病態もその成因は一様ではな く，尿毒症物質の骨髄抑制作用，赤血球寿命の短縮，血 液の体外への喪失, 鉄, 葉酸, ビ夕ミン $\mathrm{B}_{12}$ の久矢等もそ の理由とされるものの, 最も主たる要因はエリスロポエ チン (erythropoietin：EPO)の相対的欠乏状態)であ り, 動物実験での $\mathrm{EPO}$ の有用性が証明され ${ }^{3,4)}$, EPOの 補充投与は腎性貿血の最も有効な治療と考えられるに 至った。

$\mathrm{EPO}$ は主として腎臟で産生される赤血球産生調節を 司るホルモン (5)であり，約 80 年におよぶ長い研究の歴史 を有し，最近ようやくその構造が解明され，遺伝子工学 の技術により リコンビナント・ヒト・EPO (recombinant human EPO : rEPO) の大量生産が可能になっ だ。. 慢性腎不全患者に対する臨床試験で沙腎性貧血の 著明な改善が既に報告され ${ }^{7,8)}$ ，我が国においても同様に その有效性が確認されている 貧血改善後の運動耐容能の改善も示されている ${ }^{10)}$. した がって，その合理的な臨床応用は透析患者に福音をもた らすものと期待される。

今回，我乃は $\mathrm{rEPO}$ を著明な貧血を有する血液透析患 者に投与し，改善後の至適へマトクリット值レベルおよ びそれを維持するに有効な投与方法について検討し若千 の知見を得たので報告する。

なお, 本研究は昭和 63 年 4 月より 7 月にかけて実施し た.

\section{対象と方法}

\section{1. 対象患者}

対象は本試験に参加することに同意の得られたへマト クリットが $23 \%$ 末満の著明な腎性貧血を呈する維持血 液透析 (HD) を受けている慢性腎不全患者 34 例（男 17 例, 女 17 例, 年齢 23〜68 歳)で, いずれも週 3 回の HD を行っているものを対象とした。慢性腎不全の原疾患の 内訳は, 慢性系球体腎炎 24 名, 糖永病性腎症 9 名, 外傷 1 名であった。これらの患者を無作為に2 群に分け $\mathrm{A}$ 群，
表 $1 \mathrm{rEPO}$ の投与スケジュール
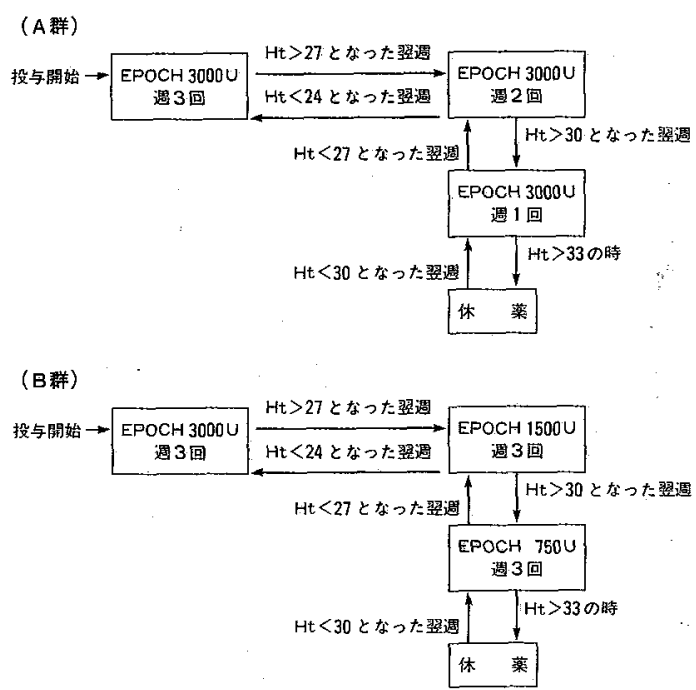

B群とした。

\section{2. 投与方法}

1) 薬剤

1 バイアル中 rEPO $750 \mathrm{IU}, 1,500 \mathrm{IU}, 3,000 \mathrm{IU}$ 含有 する凍結乾燥製剈(治験略号：EPOCH，中外製薬）を使 用時に生理食塩水 $2 \mathrm{~m} l$ 亿溶解し投与した。

2) 投与方法

透析血液回路の静脈側汃ら透析終了直前に注入した。 なお，投与に際してはショック等の反応を予測するため 十分な問診を行うとともに初回投与時には溶解した薬郕 $2 \mathrm{~m} l$ のう $0.1 \mathrm{ml}$ をまず投与し，アナフィラキシー症状 のないことを確認して本投与を行った。

3) 投与スケジュール

全例 3,000 IU 週 3 回投与により開始するが, A群, B 群, 表 1 の如く $\mathrm{Ht}$ 值に従って各週毎に投与量あるいは 投与回数を変更し 12 週間投与を行った。すなわち，A群 では 1 週当りの投与回数を，B群では 1 回当りの投与量 をそれぞれ段階的に増減することにより Ht 值を 27〜33\%の範围内に維持することとした。 


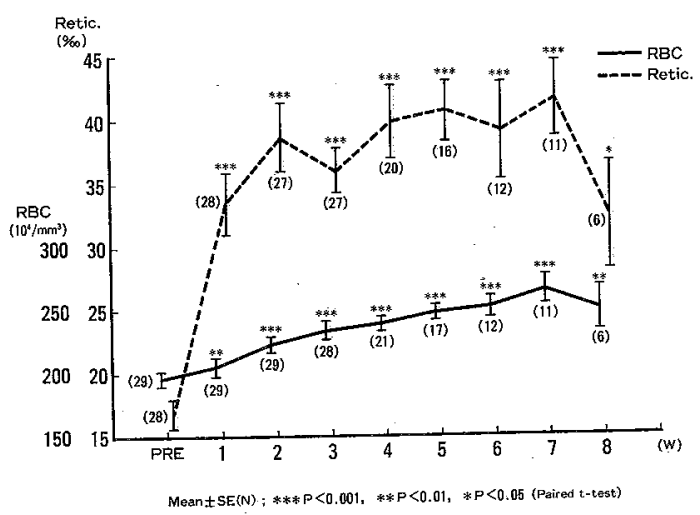

図 1 初期投与期間における赤血球数と網赤血球 数の推移

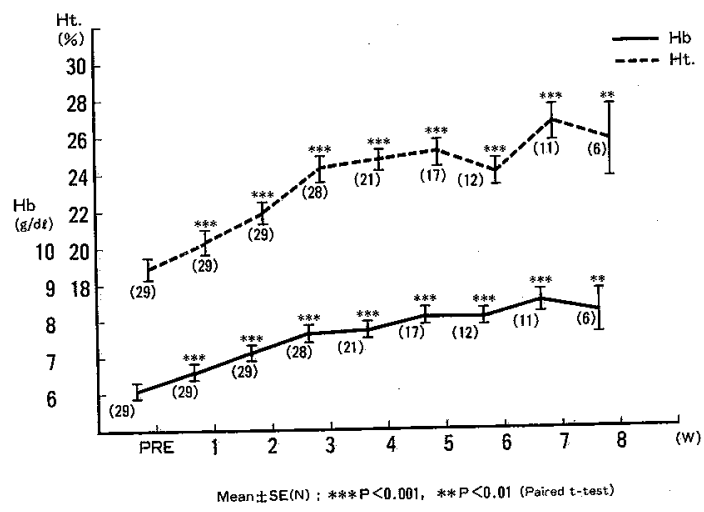

図 2 初期投与期間における $\mathrm{Hb}$ 濃度と $\mathrm{Ht}$ 值の 推移

\section{4) 併用療法 - 併用薬剤}

原則として試験期間中は一定としたが, 鉄欠乏が生じ た場合は鉄剤を使用することとした，また，免疫抑制剤， アンドロジェン, 蛋白同化ステロイドの使用は禁じた。

\section{5) 評価方法}

投与前より 1 週毎に臥位血圧, 脈拍数, 体重の测定及 び血液学的検査を行い, 投与方法の検討, 副作用のチェッ クを行った。また，自他覚症状の観察については 4 週毎 に行った。

\section{結果}

投与の終了した 34 例のうち, 不規則投与の症例, 第 1 週で輸血を行った症例，透析中に失血をきたし維持投与 移行をできなかった症例，転院した 2 症例の 5 例を除く 29 例について，1. 初期投与（rEPO 3000 IU 週 3 回投 与）時での検討，2. $\mathrm{Ht}$ が $27 \%$ に達してからの維持投 与期間での検討を行った。また，投与前後での有効性， 安全性等の評価は 34 例全例で行った。
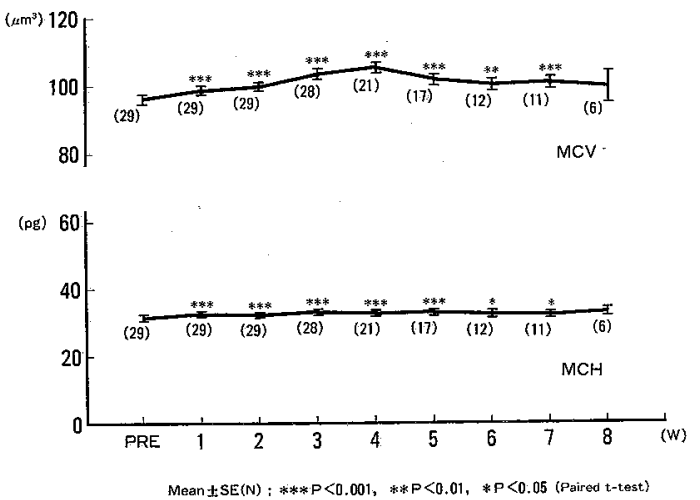

図 3 初期投与期間にお ける平均赤血球容積 $(\mathrm{MCV})$ と平均赤血球 $\mathrm{Hb}$ 濃度 (MCH) の推移

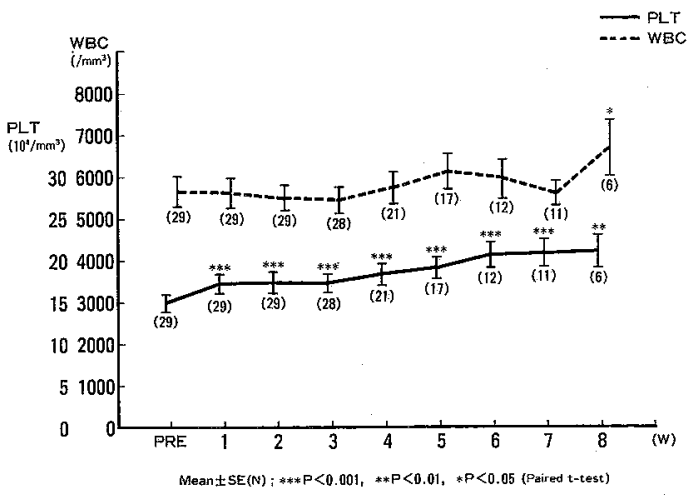

図 4 初期投与期間における血小板数と白血球数 の推移

\section{1. 初期投与}

$\mathrm{rEPO}$ 投与後の週毎の血液学的検查值の推移を図 1 〜 4 に示した。網赤血球, 赤血球数及びへモグロビン濃 度 $(\mathrm{Hb}), \mathrm{Ht}$ 值は投与 1 週後より有意に上.昇し $(\mathrm{p}<$ 0.01〜0.001), 維持投与に至るまでその上昇を続けたが， 網赤血球は約 2 週でプラトーとなり，8週では低下の傾 向を恝めた. また, 平均赤血球容積及び平均赤血球 $\mathrm{Hb}$ 濃 度も 1 週後より有意に増加し $(\mathrm{p}<0.001)$, その值を維 持している.同様に血小板数も正常範囲内で有意に増加 しその值を維持したが, 白血球数では殆ど一定の傾向を 認めなかった。 Ht 值が $27 \%$ を越えるまでの rEPO 3,000 IU 週 3 回の投与期間は 3 週から 12 週にわたった。

貧血の改善に伴う血圧の推移（図 5) では，拡張期血 圧 (DBP) で 6 週後に有意に増加 $(\mathrm{p}<0.01)$ を示した ものの，その他の時期及び収縮期血圧（SBP）の全過程 では一定の傾向を認めなかった。

\section{2. 維持投与}

Ht が $27 \%$ を越えた翌週より，維持投与に移行し，結 
表 2 維持投与方法を評価できた患者における 群，B群間での臨床デー夕の比較

\begin{tabular}{|c|c|c|c|c|c|c|}
\hline & & & $\begin{array}{c}\text { 計 } \\
(29 \text { 例) }\end{array}$ & $\begin{array}{l}\text { A 群 } \\
\text { (14 例) }\end{array}$ & $\begin{array}{l}\mathrm{B} \text { 群 } \\
\text { (15 例) }\end{array}$ & $\begin{array}{c}\text { A-B 間検定 } \\
\text { (t-test, U-test) }\end{array}$ \\
\hline 性 別 & & $\begin{array}{l}\text { 男 } \\
\text { 女 } \\
\end{array}$ & $\begin{array}{l}15 \\
14 \\
\end{array}$ & $\begin{array}{l}9 \\
5 \\
\end{array}$ & $\begin{array}{l}6 \\
9 \\
\end{array}$ & NS \\
\hline \multicolumn{2}{|l|}{ 年 齢 } & （歳） & $44.6 \pm 1.8$ & $44.9 \pm 3.1$ & $44.3 \pm 2.0$ & NS \\
\hline \multicolumn{2}{|c|}{ 体重（透析後值） } & $(\mathrm{kg})$ & $49.2 \pm 1.5(28)$ & $52.3 \pm 2.1$ & $46.2 \pm 1.8(14)$ & $\mathrm{p}<0.05$ \\
\hline \multicolumn{2}{|c|}{ 血液透析期間 } & (か月) & $85.0 \pm 9.3$ & $87.8 \pm 15.6$ & $82.3 \pm 11.1$ & NS \\
\hline $\begin{array}{l}\text { 投与前の } \\
\text { 輸血 }\end{array}$ & & $\begin{array}{l}\text { なし } \\
\text { あり }\end{array}$ & $\begin{array}{l}17 \\
12 \\
\end{array}$ & $\begin{array}{l}6 \\
8 \\
\end{array}$ & $\begin{array}{r}11 \\
4 \\
\end{array}$ & NS \\
\hline \multirow{2}{*}{ 血 圧 } & SBP & $(\mathrm{mmHg})$ & $148.8 \pm 4.8$ & $148.6 \pm 7.1$ & $149.1 \pm 6.7$ & NS \\
\hline & DBP & $(\mathrm{mmHg})$ & $79.8 \pm 2.1$ & $79.7 \pm 2.9$ & $79.9 \pm 3.2$ & NS \\
\hline \multicolumn{2}{|c|}{ ヘマトクリット值 } & $(\%)$ & $18.89 \pm 0.54$ & $18.04 \pm 0.84$ & $19.66 \pm 0.64$ & NS \\
\hline \multicolumn{2}{|l|}{ 網赤血球 } & $(\%)$ & $16.73 \pm 1.10(28)$ & $16.75 \pm 1.34$ & $16.71 \pm 1.78(14)$ & NS \\
\hline \multicolumn{2}{|l|}{ 血小板数 } & $\left(10^{4} / \mathrm{mm}^{3}\right)$ & $14.88 \pm 0.91$ & $15.26 \pm 1.22$ & $14.53 \pm 1.38$ & NS \\
\hline \multicolumn{2}{|l|}{ 白血球数 } & $\left(10^{2} / \mathrm{mm}^{3}\right)$ & $56.45 \pm 3.51$ & $50.29 \pm 2.66$ & $62.20 \pm 6.06$ & NS \\
\hline
\end{tabular}

例数または Mean $\pm \mathrm{SE}$ （）内は欠測のある場合の N, NS : p >0.05

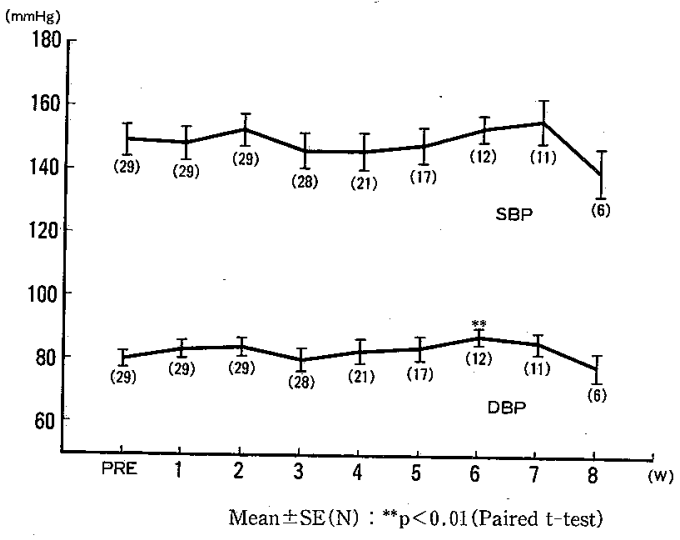

图 5 初期投与期間に打ける血圧の推移

果として表 2 に示す通り，結果としてA群 $(\mathrm{N}=14)$ と $\mathrm{B}$ 群 $(\mathrm{N}=15)$ とでは，体重がA群で有意に（p<0.05） 多かった以外には投与前後の臨床デー夕には有意差を認 めなかった。

図 6 に症例毎の $\mathrm{Ht}$ 值の推移を群別に示した。

維持投与移行後, 目標の $\mathrm{Ht}$ 値 $27 \sim 33 \%$ の範囲に良く 維持されたが, A群では Ht 值が最高で $38.5 \%$ ，最低で $25.9 \%$ となった症例を含め, 目標範囲を外れる場合が多 かった. 1 週当りの投与総量は $\mathrm{Ht}$ 值の上昇でA群では $9,000 \mathrm{IU} \rightarrow 6,000 \mathrm{IU} \rightarrow 3,000 \mathrm{IU}, \mathrm{B}$ 群では 9,000 IU $\rightarrow 4,500$ $\mathrm{IU} \rightarrow 2,250 \mathrm{IU}$ と変更されるため群間で若干異なる点は 考慮する必要があるものの, 維持投与後の観測数のうち 範囲を逸脱した回数割合を比較すると，A群 $22.0 \%$ (18/

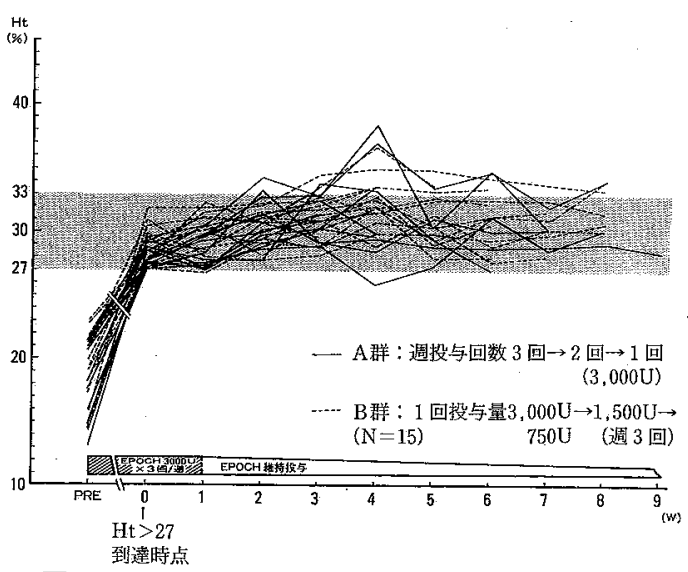

図 6 維持投与期間における症例各々の $\mathrm{Ht}$ 值の 推移

82)，B群 17.0\%（18/106）で，逸脱した Ht の範囲も $\mathrm{A}$ 群 $+5.5 \%$ - $4.1 \%, \mathrm{~B}$ 群+3.7\% - $1.4 \%$ と B群で の維持がより良好であったが，分散分析（F検定）の結 果有意差は認めなかった。 また, 平均値としては, 図 7 に示す通り, 両群とも維持投与 3 週後に最高值 (A群 $31.79 \pm 1.02$ (SE) \%，B群 $32.10 \pm 0.61 \%$ ）となり, 維 持投与移行時からも有意に高値を示したが，群間には差 は認めなかった。

12 週にわたる $\mathrm{rEPO}$ 投与中, 副作用は 34 例中 4 例に 発現したが, 何れも頭痛または血圧上昇であり, 初期投 与時に認められたが，投与を継続することが可能であっ た。 その他の問題となる副作用は認められなかった。 


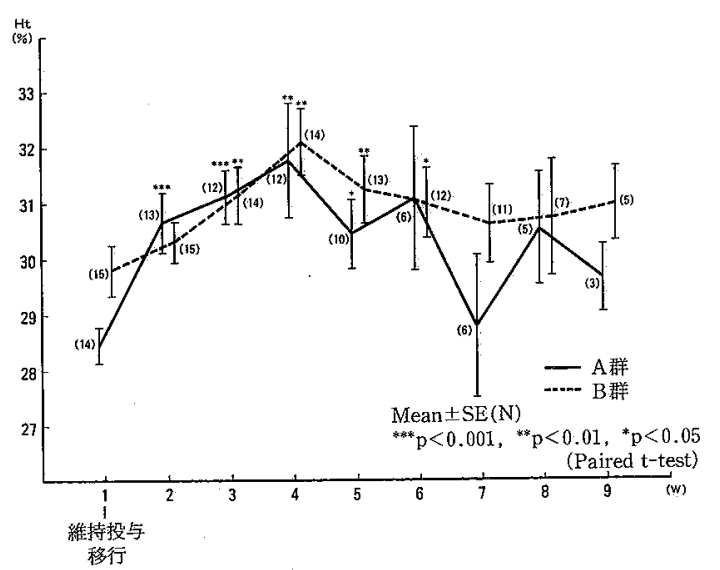

図 7 維持投与期間における両群の $\mathrm{Ht}$ 值の推移

なお，自他覚症状については，階段昇降時の息切れ， 動悸, 食欲不振, 易疫労感は 4 週の早期より消失あるい は改善して抢り, 症状の消失率は, 経時的に徐々に高く なる傾向を示した（図 8 ）。

\section{考察}

我が国における慢性腎不全維持血液透析患者を対象と した rEPO の臨床試験において腎性貧血に対してその 有効性が既に確かめられているが，rEPO による腎性貧 血の改善後その維持投与にあたり貧血の程度をどのレべ ルに置くかということが問題となる。 rEPO を投与によ り赤血球, 網赤血球以外に血小板の有意な増加が起こ $\eta^{11)}, \mathrm{EPO}$ は巨核系幹細胞の分化，増殖誘導作用をも有 することは既に報告されておりり ${ }^{12,13)}$ ，今回の検討でも同 様の結果が得られた。血小板の増加はへマトクリット (Ht) の増加による血液粘調度の増加と相乗して血栓症 を合併する可能性が指摘され，血液透析患者における シャント閉塞や，血液透析効率の低下も問題となる。 た, Ht を正常域まで回復されることによりこれらの危険 をさらに高めることが予想される。したがって，筫血の 指標としてのへモグロビン $(\mathrm{Hb}), \mathrm{Ht}$ 值の至適レベルを どこに設定するかという問題とともにそれを維持するに 有効な投与方法が検討すべき課題となる.

今回の検討で貧血のレベルとして Ht 值を $27 \sim 33 に$ 設定したが 3 か月の観察期間中に血栓症は一例もなく, また透析治療上の問題も特に認めずに, 自他覚症状の著 明な改善が得られた。平沢 ${ }^{14)}$ もt $30 \%$ 程度を日常生活 や, 通常の作業に体力的にほほ対応できるレベルとして 一応の目標值と推定している。

また，その維持投与方法別にみても投与回数漸減法 (A), 投与量漸減法（B）ともに有効性, 安全性が確認 された。

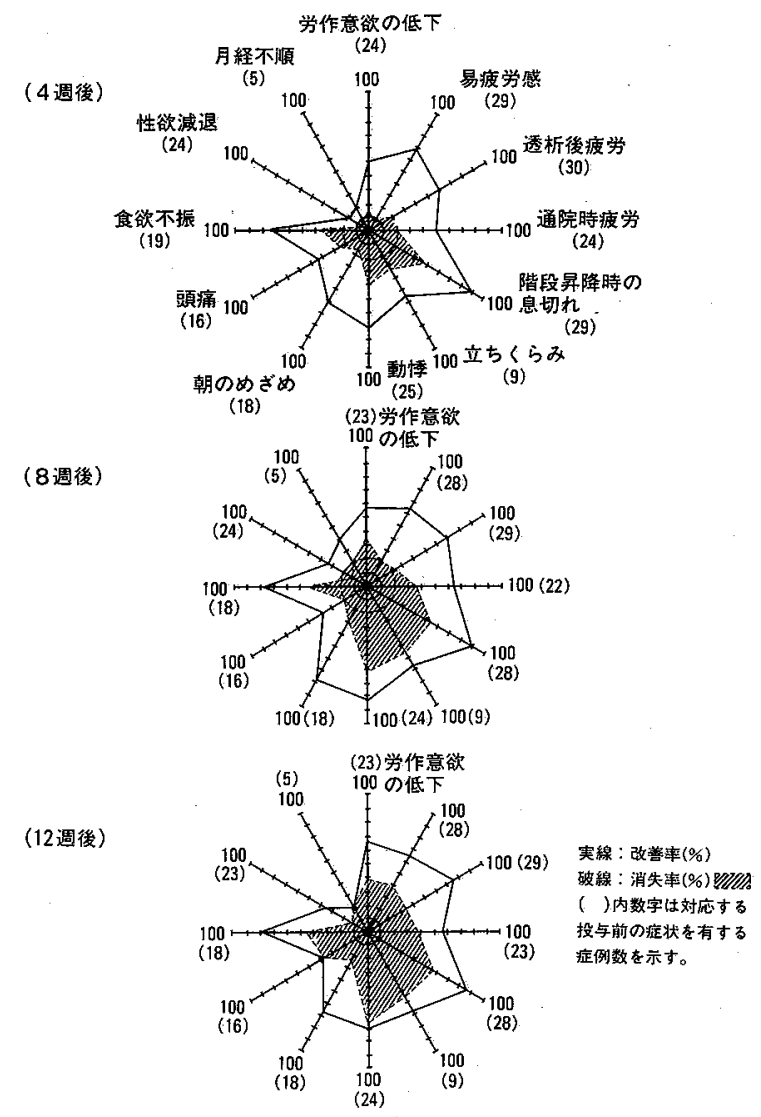

図 8 自他覚症状の消失率, 改善率の推移

しかしながら, $\mathrm{Ht}$ 值が 27 33 に至った維持投与期間 において個々の症例でみると統計学的には群間で差を認 めないものの, A群では B 群と比較し $\mathrm{Ht}$ 值の変動が大 きい印象を受け, A群とB群とでは 1 週間の投与量を比 較すると減量にともない $\mathrm{B}$ 群が少量となり，このことも 考慮すべきであるが，A群では設定 $\mathrm{Ht}$ を逸脱する程度 も大きく, 全体でも $\mathrm{A}$ 群では平均 $\mathrm{Ht}$ 值の変動さらには 各週に扔ける $\mathrm{Ht}$ 值の変動も B 群と比較してやや大き く,Ht のレベルを一定に維持するためには投与回数での 調節より投与量での調節の方が好ましいと考えられる。 多施設に㧧ける血液透析患者対する $\mathrm{rEPO}$ の単回投与 試験 ${ }^{15)}$ において静注後の血中 EPO 濃度の推移はラジオ イムノアッセイで測定すると 48 時間後にはほぼ投与前 值近くに低下し, 半減期は $1,800 \mathrm{IU}$ では $9.4 \pm 0.9$ 時間, $3,600 \mathrm{IU}$ では $9.7 \pm 0.9$ 時間程度であった．このことも血 液透析毎の週 3 回投与により血中 EPO 濃度をある有効 濃度に保つことが EPO の標的細胞である後期赤芽球前 駆細胞 (CFU-E) 抢よびそれ以前の幼弱が赤血球系幹細 胞の分化誘導の持続に重要であることを示唆しているも 
のと考えられる.何れにしても，1週あたりの投与量の 比較もふくめ今後検討すべき課題である。

このように，透析患者に扔いて重大な合併症を回避し つつ, rEPO 投与による貧血の改善が最大限の体力とく に持久力の回復ももたらすに可能な貧血の至適レベルを ぞの様に設定するか，また，それを一定に維持する最善 の投与方法については今後も症例を重ね, 長期的に検討 されるべきである、しかしながら，今回検討したような 画一的なスケジュールで投与することが貧血の設定レベ ル維持に最適かどうかは疑問の残る点であり，その投与 方法の選択については長期の観察により個々の症例に応 じてはなされるべきかも知れない.

透析患者の貧血に対する $\mathrm{rEPO}$ の投与が我が国にお いて近くに臨床応用されようとしているが，それにより もたらされる筫血改善がこれら患者の社会復帰の一助と なることが益々期待される。

\section{結論}

著明な貧血を呈する慢性腎不全血液透析患者にりコン ビナント・ヒト・エリスロポエチンを初期投与として 3 , $000 \mathrm{IU}$ 週 3 回で行い, ヘマトクリット (Ht) 值 27\%達し えた時点から $27 \%$ タ3\%に維持するように投与量ある いは投与回数の増減を行い以下の結果を得た。

1) 初期投与で 1 週後より有意の上昇を認め, $3 \sim 12$ 週で Ht 值 27\%に達した。

2) 維持投与方法としては投与間隔を変えず，1回投 与量を増減する方法が Ht の一定レベル維持に有効であ るとの感触が得られたが，週当りの総投与量が異なるこ とも考慮する必要がある.

3 ）副作用は 4 例において認められ，いずれも血圧上 昇, 頭痛で投与を継続することが可能であった。その他， 貧血改善に伴う血栓症，シャントトラブルは認められな かった.

本論文の要旨は第 34 回日本透析療法学会において発 表した.

\section{文献}

1) Barner N, Drory Y, Lapidot C, Reisin E, Eliahou $\mathrm{H}$, Kellermann JJ : Exercise tolerance in patients on chronic hemodialysis. Israel J Med Sci $16: 17$ $-21,1980$

2）秋沢忠男, 穴戸寛治, 高橋 健, 越川昭三：腎性貧 血の成因と治療. 臨床成人病 $15 ： 1851-1853 ， 1985$

3) Eschbach JW, Mladenovic J, Garcia JF, Wahl $\mathrm{PW}$, Adamson JW : The anemia of chronic renal failure in sheep. Response to erythropoietin in plasma in vivo. J Clin Invest $74: 434-441,1984$

4) Masunaga $H$, Goto M, Ueda M : Effect of purified erythropoietin in partially nephrectomized rats. Acta Haematol Jpn 49 : 807-815, 1986

5) Jacobson LO, Goldwasser E, Fried W, Plzak L : Role of kidney in erythropoiesis. Nature $179: 633$ $-643,1957$

6) Jacobs $K$, Shoemaker C, Rudersdorf R, Niell SD, Kaufman RJ, Mufson A, Seehra J, Jones SS, Hewick R, Fritsch EF, Kawakita M, Shimizu T, Miyake $\mathrm{T}$ : Isolation and chracterization of genomic and cDNA clones of human erythropoietin. Nature $313: 806-810,1985$

7) Wineals CC, Oliver DO, Downing MR, Cotes PM : Effect of human erythropoietin derived from recombinant DNA on anaemia of patients maintained by chronic haemodialysis. Lancet ii : 1175-1177, 1986

8) Eschbach JW, Egrie JC, Downing MR, Browne $\mathrm{JK}$, Adamson JW : Correction of the anemia of end-stage renal disease with recombinant human erythropoietin, N Engl J Med 316 : 73-78, 1987

9）平沢由平, 平嶋邦猛, 荒川正昭, 小高通夫, 小椋陽 介, 吉川康行, 佐中 孜, 篠田 晤, 森井浩世, 鈴 木正司, 大平整爾, 千葉栄市, 高橋 寿, 金田 浩, 前多隆吉, 山形 陽, 浅野, 泰, 武藤重明, 内田信 一, 下条文武, 栗原 怜, 田畑陽一郎, 藤井京子, 嶋田俊恒, 中澤了一, 吉田豊彦, 波多野道信, 高橋 進, 井上通泰, 小出 輝, 窪田 実, 中山秀英, 吉 山直樹, 秋葉 隆, 黑川 清, 星野正信, 猿田享男, 鈴木洋通, 小路 良, 佐藤哲平, 杉野信博, 石田尚 志, 大和田滋, 杉山 誠, 越川昭三, 高橋 健, 磯 田和男, 今村典嗣, 菅 英育, 丸茂文昭, 塚本雄介, 坂本信夫, 渡辺有三, 出崎親雄, 澤西謙次, 小野利 彦, 折田義正, 飯田喜俊, 椿原美治, 岡田倫之, 井 上 隆, 日野雅之, 前川正信, 田中 寛, 白井大禄, 藤田嘉一, 井上聖士, 坂井瑠実, 小野山薰, 中村定 敏, 藤見 惺, 保利 敬, 中山眞人, 出口隆志, 小 川暢也：腎性筫血に対する recombinant human erythropoietin の臨床的検討. 臨妝透析 5 : 585-602, 1989

10) Mayer G, Thum J, Cada EM, Stummvoll HK, Graf $\mathrm{H}$ : Working capacity is increased following recombinant human erythropoietin treatment. Kidney Int $38: 525-528,1988$

11) Bommer J, Müller-Bühl E, Ritz E, Eifers J : 
Recombinant human erythropoietin in anaemic patients on haemodialysis. Lancet i : 392, 1987

12) Clark DA, Dessypris EN : Effects of recombinant erythropoietin on murine megakaryocytic colony formation in vitro. J Lab Clin Med $108: 423-429$, 1986

13) Dessypris, EN, Gleaton JH, Armstrong OL: Effect of human erythropoietin on human marrow megakaryocyte colony formation in vitro. $\mathrm{Br} \mathrm{J}$ Haemat 65 : 265-269, 1987
14）平沢由平：エリスロポエチンの今後の問題. 腎と透 析 $26: 65-70,1989$

15）平沢由平, 平嶋邦猛, 小椋陽介, 小高通夫, 嶋田俊 恒, 吉川康行, 荒川正昭, 下条文武, 二宮 裕, 藤 原敬人, 近 ·幸吉, 鈴木正司, 佐藤哲平, 篠田 晤, 森本幸子, 四蔵直人, 桝崎繁喜, 森井浩世, 日野雅 之：血液透析患者に対する recombinant human erythropoietin の単回投与試験. 臨牀透析 5 : 453-460, 1989 